\title{
The Timing of Goodwill Write-off: Cases of Initial Overpayment
}

\author{
Jamaliah Abdul Majid $^{1}$, Robiah Abu Bakar ${ }^{1}$, Nor Asma Lode ${ }^{1}$ \\ ${ }^{1}$ School of Accountancy, College of Business, Universiti Utara Malaysia, 06010 Sintok, Kedah, Malaysia \\ Correspondence: Jamaliah Abdul Majid, School of Accountancy, College of Business, Universiti Utara Malaysia, \\ 06010 Sintok, Kedah, Malaysia. E-mail: jamaliah@uum.edu.my
}

Received: August 23, 2016

Accepted: September 6, 2016

Online Published: September 26, 2016

doi:10.5539/ibr.v9n11p65

URL: http://dx.doi.org/10.5539/ibr.v9n11p65

\begin{abstract}
This paper explores types of accounting choice related to reporting goodwill impairment losses, if any, exercised by Malaysian listed firms after an implementation of IFRS 3. The study is carried out through an in-depth analysis of annual reports for fifteen firms over a number of years. The fifteen firms selected are those that have goodwill arising from business combinations in December 2006/7, reported goodwill impairment losses in the current year or the future year(s), and the goodwill represents $50 \%$ or more of the acquisition price. Results show that of the fifteen firms examined, eight firms appeared to exercise the accounting choice in the form of opportunistic timing in reporting the impairment losses. The study contributes to the accounting choice literature by providing evidence on the timing of goodwill impairment losses for goodwill that arose from an apparent overpayment made at the time of an acquisition of a subsidiary.
\end{abstract}

Keywords: opportunistic reporting, accounting choice, goodwill impairment, business combinations, acquisitions

\section{Introduction}

The present study explores types of accounting choice related to reporting goodwill impairment losses, if any, exercised by Malaysian listed firms after an implementation of IFRS 3 Business Combinations. Following Fields et al. (2001), accounting choices are identified by the implementation decisions made by managers, in particular, through judgments and estimates employed in performing an impairment test of goodwill.

IFRS 3 was issued by the International Accounting Standards Board (IASB) in 2001 and was first implemented by the European listed firms in 2005. In Malaysia, the IFRS 3 was implemented by its public listed firms in 2006. The implementation of the IFRS 3 resulted in an impairment-only approach in accounting treatment for acquired goodwill (IASB, 2006). One of the main reasons for the implementation of the impairment-only approach was because IASB views that permitting choices in accounting treatments for acquired goodwill impairs the usefulness of the information presented on the financial statements (IASB, 2006). Thus, the impairment-only approach required by the IFRS 3 implies that there is no longer a choice of accounting methods related to subsequent accounting for goodwill exercised by listed firms.

Nevertheless, prior studies (e.g., Fields et al., 2001; Francis, 2001; Abdul Majid, 2013; Abdul Majid, 2015) argue that accounting choice exists not only through the selection of accounting methods but also via implementation decisions. Francis (2001) explained that the implementation decisions include estimates and judgments applied by managers in implementing the Generally Accepted Accounting Principles (GAAP). In the case of an impairment of assets including goodwill, there are covert options and estimations, such as in the recognition of the impairment and the application of the discount rates (Kvaal and Nobes, 2010).

The consideration of implementation decisions as one of the essential elements of accounting choice, as highlighted by Fields et al. (2001), widen the scope of accounting choice studies. Accordingly, Francis (2001) recommends more research in examining specific accounting items that involve managerial judgments and have significant impact on firms' reported earnings (Abdul Majid, 2013). The reason is because managers could be exercising the judgement to convey firms' private information or to engage in opportunistic reporting (Healy and Wahlen, 1999, Fields et al., 2001, Francis, 2001; Abdul Majid, 2013).

Motivated by the recommendation made by Francis (2001) for additional research that examine the implementation decisions of specific accounting items, the present study seeks to explore types of accounting choices related to reporting goodwill impairment losses, if any, exercised by Malaysian listed firms following the implementation of IFRS 3. 


\section{Review of Literature}

In the present study, the definition of accounting choice is adopted from Fields et al. (2001), as follows:

"An accounting choice is any decision whose primary purpose is to influence (either in form or substance) the output of the accounting system in a particular way, including not only financial statements published in accordance with GAAP [Generally Accepted Accounting Principles], but also tax returns and regulatory filings" (Fields et al. 2001: 256).

The rationale for adopting this definition is because it is comprehensive. As discussed by Francis (2001), this definition is wide-ranging as it covers several accounting choices that were examined by prior studies. It also includes judgements and estimates as well as timing decisions in implementing GAAP. Francis (2001) elaborates that example of timing decisions are firms' actions in delaying adopting certain accounting rules or their actions in early adopting the rules, especially when there is flexibility in the timing of the adoption.

Thus far, prior studies that examined the timing of goodwill write-offs focused on listed firms in advanced economies, such in the US (e.g., Henning et al., 2004; Hayn and Hughes, 2006) and Australia (e.g., Ji, 2013). Henning et al. (2004), for example, examined whether US listed firms made use of the discretion afforded by the US GAAP prior to the implementation of SFAS 142 to manage the timing of goodwill write-offs. Their findings suggest that the listed firms they examined appear to delay the goodwill write-offs.

Similar to Henning et al. (2004), Hayn and Hughes (2006) also focused on US listed firms and examined the timeliness of the goodwill write-offs of these firms prior to the implementation of SFAS 142 that required an impairment-only approach to acquired goodwill. Based on 1,276 acquisitions made from 1988-1998 of the US listed firms, they found that goodwill write-offs of these firms lags behind their economic impairment by an average of 3-4 years. In addition, Hayn and Hughes (2006) reported that in one-third of the firms analysed, the delay of goodwill impairment extended up to 10 years.

Unlike Henning et al. (2004) and Hayn and Hughes (2006), Ji (2013) examined the timing of goodwill write-off after the implementation of an impairment-only approach to acquired goodwill. Focusing on 77 Australian listed firms from 2007-2009, the findings of the study suggest that the Australian listed firms that she examined delayed the goodwill write-offs.

In the context of asset write-offs and goodwill impairment, prior studies that analysed accounting choice generally applied the opportunistic behaviour perspective (Abdul Majid, 2013) and the contracting perspective (Abdul Majid, 2017). These perspectives posit that managers made use of the discretion available in the standard (Francis et al., 1996; Hilton and O’Brien, 2009). Reasons for such managerial opportunism are explained in the context of the reporting behaviour of the incoming Chief Executive Officer (CEO) or the continuing CEO, earnings smoothing activities and big bath reporting behaviour (Abdul Majid, 2013). Hilton and O'Brien (2009: 180) added that one of the motives for firms to inflate the asset values (by delaying goodwill write-off) is due to the desire to create an "illusion of financial strength".

\section{Research Design}

To explore types of accounting choices related to reporting goodwill impairment losses, if any, exercised by Malaysian listed firms following an implementation of the IFRS 3, the present study focuses on firms that fulfilled the following three criteria. First, firms that have goodwill, which arose from business combinations for the financial year ended 31 December 2006/7. Second, these firms reported goodwill impairment losses in the current year or the future year(s). Third, the goodwill represents $50 \%$ or more of the acquisition price.

Table 1 shows that there are twenty four firms that have goodwill arising from business combinations for the financial year ended 31 December 2006/7 and reported goodwill impairment losses in the current year or the future year(s). From these twenty four firms, nine firms have goodwill that represents less than $50 \%$ of the acquisition price while seven firms do not provide detailed information concerning the acquisition of a subsidiary that resulted in goodwill. Overall, there are eight firms which have goodwill that represents $50 \%$ or more of the acquisition price.

To explore the types of accounting choices related to reporting goodwill impairment losses, the present study focuses on the eight firms and examined their annual reports in detailed in three stages. In the first stage, we identified the additional goodwill that arose from an acquisition of subsidiary companies. Next, based on the amount of the additional goodwill, we traced back the investment in subsidiary companies that resulted in the goodwill. In the final stage, we traced the amount of goodwill impairment losses reported by the companies starting from the year of the acquisition to the future year(s). 
Table 1. Selection of data

\begin{tabular}{lc}
\hline & Number of firms \\
\hline Firms that have goodwill arising from business combinations for the financial year ended 31 & 24 \\
December $2006 / 7$ and reported goodwill impairment losses in the current year or future year(s) & (9) \\
Less: Firms that have goodwill which represent less than 50\% of the acquisition price & (7) \\
Less: Firms that do not provide detailed information concerning the acquisition of a subsidiary & 8 \\
that resulted in goodwill \\
The final number of firms that have goodwill which represent $50 \%$ or more of the acquisition \\
price
\end{tabular}

\section{Results and Discussion}

Detailed analysis of firms' annual reports revealed that although all of the eight firms have significant amount of goodwill relative to the acquisition price, the timing in reporting the impairment losses varies. Out of the eight firms, four of them will be discussed in this study (see Tables 2 to 5). These four firms (i.e. Entity ${ }^{1}$ A to Entity D) are selected to demonstrate differences in the timings of the reporting of goodwill impairment losses for goodwill that arose from an apparent overpayment at the time of an acquisition of a subsidiary.

Tables 2 to 5 show that for each of the four firms, goodwill represents more than $65 \%$ of the acquisition price. It is noted that the large amount of goodwill relative to the acquisition price itself is not an accounting choice related to reporting goodwill impairment losses. Rather, the accounting choices emerge as a result of the decisions made by managers regarding the timing in reporting the impairment losses.

To illustrate, all of the four companies as shown in Tables 2 to 5 have a significant amount of goodwill relative to acquisition price and all of them reported goodwill impairment losses. Three companies reported the impairment losses as soon as possible. For example, Entity A fully impaired the goodwill immediately in the year of acquisition (see Table 2), Entity B fully impaired the goodwill in the subsequent year (see Table 3) and Entity C impaired the goodwill within a period of two years (see Table 4). For Entity C, 57\% of the goodwill was impaired in the year of acquisition and the remaining $43 \%$ of the goodwill was impaired in the subsequent year.

Table 2. An analysis of an acquisition of subsidiary firms for Entity A during the financial year ended 31 December 2007

\begin{tabular}{llll}
\hline Date & & RM & $\%$ \\
\hline 2007 & Addition: & 580,270 \\
& Group's share of net assets & $1,635,192$ & $95 \%$ \\
& Goodwill arising from acquisition & & \\
& Excess of group's interest in the net fair value acquired & & \\
& over the cost of acquisition in a subsidiary & $(488,806)$ \\
& Cost of acquisition & $1,726,656$ \\
& Notes: & & $1,635,192$ \\
$31 / 12 / 2007$ & Goodwill impairment loss reported in 2007 & $100 \%$ \\
\hline
\end{tabular}

Table 3. An analysis of an acquisition of subsidiary companies for Entity B during the financial year ended 31 December 2007

\begin{tabular}{llll}
\hline Date & & RM & $\%$ \\
\hline $26 / 12 / 2006$ & Addition: & 69,182 & \\
& Group's share of net assets & 160,809 & $70 \%$ \\
& Goodwill arising from acquisition & 229,991 & \\
& Cost of acquisition & & $0 \%$ \\
$31 / 12 / 2006$ & Notes: & - & 160,809 \\
$31 / 12 / 2007$ & Goodwill impairment reported in 2006 & $100 \%$ \\
\hline
\end{tabular}

\footnotetext{
${ }^{1}$ The names of the four firms are anonymised.
} 
Table 4. An analysis of an acquisition of subsidiary companies for Entity $\mathrm{C}$ during the financial year ended 31 December 2006/7

\begin{tabular}{llll}
\hline Date & & RM & $\%$ \\
\hline $10 / 1 / 2006$ & Addition: & 52,434 & \\
& Group's share of net assets & 100,701 & $66 \%$ \\
& Goodwill arising from acquisition & 153,135 & \\
& Cost of acquisition & & \\
$31 / 12 / 2006$ & Notes: & 57,783 & $57 \%$ \\
$31 / 12 / 2007$ & Goodwill impairment reported in 2006 & $43 \%$ \\
& Goodwill impairment reported in 2007 & 100,701 & \\
\hline
\end{tabular}

On the other hand, Entity D that has the largest amount of goodwill, reported goodwill write-off gradually year by year. As shown in Table 5, the amount of goodwill represents $82 \%$ of the acquisition price. The company impaired the goodwill from the initial year the goodwill arose to the year 2012.

Table 5. An analysis of an acquisition of subsidiary companies for Entity D during the financial year ended 31 December 2007 to 31 December 2012

\begin{tabular}{llll}
\hline Date & & RM & $\%$ \\
\hline $26 / 12 / 2007$ & Addition: & $9,288,590$ & \\
& Group's share of net assets & $43,583,190$ & $82 \%$ \\
& Goodwill arising from acquisition & $52,871,780$ & \\
& Cost of acquisition & & \\
$31 / 12 / 2007$ & Notes: & 500,782 & $1 \%$ \\
$31 / 12 / 2008$ & Goodwill impairment reported in 2007 & $2 \%$ \\
$31 / 12 / 2009$ & Goodwill impairment reported in 2008 & 886,880 & $2 \%$ \\
$31 / 12 / 2010$ & Goodwill impairment reported in 2009 & $1,035,367$ & $11 \%$ \\
$31 / 12 / 2011$ & Goodwill impairment reported in 2010 & $4,964,464$ & $26 \%$ \\
$31 / 12 / 2012$ & Goodwill impairment reported in 2011 & $11,330,050$ & $37 \%$ \\
\hline
\end{tabular}

With regards to the disclosure of the impairment losses in the notes to the financial statement, Entity $\mathrm{C}$ do not disclosed reasons for the impairment losses. Meanwhile the reasons for the impairment losses disclosed by Entity A and Entity B lack clarity. For Entity A and Entity B, the reasons disclosed in the notes to the financial statement seem to inform the shareholders that the goodwill impairment losses occur as a result of the impairment test of goodwill. For example, Entity A disclosed the following reason for the impairment of goodwill impairment loss:

"The Group recognised an impairment loss of goodwill of RM1,635,192 during the financial year based on the discounted cash flows in arriving at the value in use" (Entity A, 2006).

Similar to Entity A and Entity B, the reasons for the goodwill impairment losses disclosed in the notes to the financial statement by Entity D lacks content. The available disclosures do not provide users of financial statement sufficient information to assess the value of goodwill reported on the balance sheet. In addition, Entity D disclosed the same reason for the impairment losses reported for the year 2007 to 2010 and alter the wordings slightly in the annual report dated 2012.

Overall, from the analyses of the acquisitions of subsidiary companies for these four firms, it seems that the managers have already decided to impair the goodwill and they chose the timing of the impairment losses. Therefore, the reporting of goodwill impairment losses for these firms provides evidence of opportunistic timing in reporting the write-off.

\section{Conclusions}

The present study has explored types of accounting choice related to reporting goodwill impairment losses exercised by Malaysian listed firms after an implementation of IFRS 3. Focusing on listed firms with goodwill that represents $50 \%$ or more of the acquisition price, an in-depth analysis of firms' annual reports over a number of years has been undertaken. The analysis has provided evidence of an opportunistic timing in the goodwill write-offs. This opportunistic timing is observed through managers' decisions when to fully impair the goodwill. Although all of the listed firms examined have significant amount of goodwill relative to the acquisition price, their timing in reporting the write-off differ. Some firms chose to take the goodwill write-off immediately in the year of acquisition while other firms decided to write-off the goodwill gradually.

In conclusion, focusing on firms with goodwill that arose from an apparent overpayment made at the time of an acquisition of a subsidiary, the present study has contributed to the accounting choice literature. This is 
accomplished by providing preliminary evidence on the timing of goodwill write-off of these Malaysian listed firms after the implementation of IFRS 3.

\section{Acknowledgements}

Financial support from the Universiti Utara Malaysia via the LEADS research grant is gratefully acknowledged. Part of this paper is based on a Ph.D. thesis of the first author, completed at the University of Glasgow, Scotland, UK.

\section{References}

Abdul, M. J. (2013). Accounting choices relating to goodwill impairment: Evidence from Malaysia. Unpublished $\mathrm{PhD}$ thesis. University of Glasgow, Scotland, United Kingdom.

Abdul, M. J. (2015). Reporting incentives, ownership concentration by the largest outside shareholder, and reported goodwill impairment losses. Journal of Contemporary Accounting \& Economics. http://dx.doi.org/doi.org/10.1016/j.jcae.2015.07.002

Abdul, M. J. (2017). Audit committee independence and a contracting perspective on goodwill impairment: Singaporean evidence. Business: Theory and Practice, forthcoming.

Fields, T. D., Lys, T. Z., \& Vincent, L. (2001). Empirical research on accounting choice. Journal of Accounting and Economics, 31, 255-307. http://dx.doi.org/10.1016/S0165-4101(01)00028-3

Francis, J. (2001). Discussion of empirical research on accounting choice. Journal of Accounting and Economics, 31, 309-319. http://dx.doi.org/10.1016/S0165-4101(01)00017-9

Francis, J., Hanna, D. J., \& Vincent, L. (1996). Causes and effects of discretionary asset write-offs. Journal of Accounting Research, Supplement, 34(3), 117-134. http://dx.doi.org/10.2307/2491429

Hayn, C., \& Hughes, P. J. (2006). Leading indicators of goodwill impairment. Journal of Accounting, Auditing \& Finance, 21(3), 223-265.

Healy, P. M., \& Wahlen, J. M. (1999). A review of earnings management literature and its implications for standard setting. Accounting Horizons, 13, 365-383. http://dx.doi.org/10.2308/acch.1999.13.4.365

Henning, S. L., \& Shaw, W. H. (2004). The Amount and Timing of Goodwill Write-offs and Revaluations: Evidence from U.S and U.K Firms. Review of Quantitative finance and Accounting, 23, 99-121. http://dx.doi.org/10.1023/B:REQU.0000039507.82692.d3

Hilton, A. S., \& O`Brien, P. (2009). Inco Ltd.: Market value, fair value, and management discretion. Journal of Accounting Research, 47(1), 179-211. http://dx.doi.org/doi.org/10.1111//j.1475-679X.2008.00314.x

IASB. (2006). IFRS 3 Business Combinations. In International Financial Reporting Standards as at 1 January 2006 (pp. 273-394). International Accounting Standards Board (IASB), London: IASCF Publications Department.

Ji, K. (2013). Better late than never, the timing of goodwill impairment testing in Australia. Australian Accounting Review, 23(4), 369-379. http://dx.doi.org/10.1111/auar.12036

Kvaal, E., \& Nobes, C. (2010). International differences in IFRS policy choice: a research note. Accounting and Business Research, 40(2), 173-187. http://dx.doi.org/10.1080/00014788.2010.9663390

\section{Copyrights}

Copyright for this article is retained by the author(s), with first publication rights granted to the journal.

This is an open-access article distributed under the terms and conditions of the Creative Commons Attribution license (http://creativecommons.org/licenses/by/4.0/). 